\title{
Teatro español actual: «paisajes de memoria » en la obra de Laila Ripoll, Itziar Pascual y Gracia Morales
}

2. Mabel Brizuela / Universidad Nacional de Córdoba / mabibrizuela@gmail.com

\section{Resumen}

Este trabajo presenta a tres prestigiosas dramaturgas del teatro español actual. Laila Ripoll, Itziar Pascual y Gracia Morales producen una escritura dramática que conjuga tradición y vanguardia, rupturas y continuidades. Su teatro tiene rasgos posmodernos, propios de una escritura nueva con marcados toques de grotesco, tragedia y "esperpento». Dentro de la diversidad temática y estructural de su obra y la singularidad de sus estéticas, nos centramos en un tema común a todas: la memoria, que marca el compromiso con su tiempo y con su historia.

Palabras clave: teatro $\cdot$ español $\cdot$ actual $\cdot$ dramaturgas $\cdot$ memoria

\section{Abstract}

This paper presents three prestigious playwrights of the current Spanish theater. Laila Ripoll, Itziar Pascual and Gracia Morales produce dramatic writing that combines tradition and modernity, ruptures and continuities. Her theater is postmodern traits of a new script with strong hints of grotesque, tragedy and "esperpento». Within the thematic and structural diversity of his work and the uniqueness of its aesthetic, we focus on a theme common to all: memory, marking the commitment to their time and their history.

Key words: Spanish theater $\cdot$ current $\cdot$ playwrights $\cdot$ memory
La trayectoria dramática de Laila Ripoll (Madrid, I964), Itziar Pascual (Madrid, 1967) y Gracia Morales (Motril, Granada, I973), que arranca en los noventa, ${ }^{1}$ alcanza en la primera década de este siglo, con su plenitud expresiva, un lugar destacado dentro del actual campo teatral español donde sus obras tuvieron muy buena acogida de público y crítica y fueron distinguidas con importantes premios como el Marqués de Bradomín y el sgaE de Teatro (Gracia Morales), el Valle Inclán y el Certamen Internacional Leopoldo Alas Minguez (Itziar Pascual), el Caja España y el José Luis Alonso (Laila Ripoll), entre otros. Cada una de ellas ha seguido un camino personal que identifica su teatro, sin embargo, dentro de
Fecha de recepción: $30 / 11 / 2014$ Fecha de aceptación: I5/12/20I4 